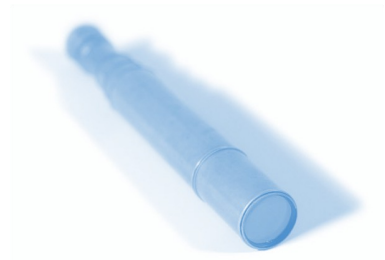

\author{
Adilah Shariff \\ Centre of Interdisciplinary \\ Science \\ University of Leicester \\ LE1 7RH \\ as460@le.ac.uk
}

\title{
Reflections on a first time experience of problem-based learning
}

\begin{abstract}
The aim of this paper is to share the author's experience of Problem-Based Learning (PBL). The paper also discuss some of the author's opinions and views about PBL and highlight some of the problems faced by the author as a facilitator as well as point out some of the problems faced by the students.
\end{abstract}

\section{Introduction}

Problem-based learning (PBL) is a total paradigm shift in teaching and learning when all learning is built around real-world problem scenarios. $\mathrm{PBL}$ is the richest learning environment that I have encountered. As an academic visitor at Leicester University I had the opportunity to observe during the facilitation sessions and the expert sessions for the undergraduate interdisciplinary science courses. These observations have helped me gained a better understanding of the role of teachers as facilitators in the PBL classrooms and also provided me with greater insights into what problem-based learning is all about. In Leicester the learning environment is based around problem-based learning (PBL) and integrates theory, computing and practical work with class and tutorial activities in a learning community. A restructured state-of -the art laboratory has been designed and built as a dedicated PBL facility and provides a unique space for teaching for group and individual study. Also there are laboratories for hands on experiments in for example physics, earth science, chemistry etc. ${ }^{1,2}$.

Problem-based learning (PBL) is an educational approach that challenges students to "learn to learn" ${ }^{3,4}$. Students work cooperatively in groups to seek solutions to real world problems and more importantly, to develop skills to become self-directed learners. Here, the goal of problem-based learning is viewed as learning for capability to acquire knowledge rather than learning for the sake of acquiring the knowledge. PBL is unique in its integral emphasis on core content along with problem solving ${ }^{5}$. Within the context of reading in a problem based learning classroom, learning thus become much more than the process of mere seeking of knowledge. Students develop critical thinking abilities by constantly relating what they read to what they want to do with the information. They question the writer's assumptions and analyse information presented, all within the context of finding answers to "What can I do with this information that I obtain?" and "What does understanding this information mean to me?" This article discusses some of the challenges in learning that students face and also presents the author's view about some of the problems that teachers face in a problem-based learning classroom. These views are based on the author's personnel reflections from class observations with some of the points and views drawn from the author's experience with the Solar Cells PBL (Appendix 1) which was conducted with the first year undergraduate students at the University of Leicester.

Opportunities for combining conceptual understanding of physics with critical thinking skills occur when the students encounter the real-world applications. Whenever possible, problems and experiments relate the basic physics principles to the real world. Students who acquire scientific knowledge in the context in which it will be used are more likely to retain what they learn and apply that knowledge appropriately ${ }^{6,7}$. The Solar Cells PBL is a first year laboratory project which was designed so that students will gain some understanding about the physics of the solar cells. Students were given with the trigger question, the suggested references and the list of equipments (Appendix 1).

PBL requires students to take on active learning strategies and adopt a self-directed learning disposition. Some students find it difficult to cope when asked to transform into active critical thinkers. PBL teachers may also face difficulty as they prepare to facilitate discussion, provide coaching, challenge student thinking and manage group work ${ }^{8}$. 
Some of the challenges for the PBL classrooms are as follows:

\section{Limited experience in group work management}

One of the weakness that my students had during the Solar Cell PBL was that they were lacking in awareness of the importance of group work and time management. I noticed that they were not fully conscious of the need to divide the work load and plan to meet together to share their findings, initiate discussion and draw a conclusion. During the laboratory session I witnessed only one student actually trying to do the experiment, while the other three students were just standing by and watching. I had to motivate the group into using most the resources provided on the work bench and also make them realise of the need to manage their time well and to keep focus on how to best achieve the group action plans for the project as a team. As group work is integral to PBL and students need to learn how to make optimal use of their time and resources, I tried to coach my students on how to function effectively in as a team. This involves cultivating skills to know how to organize the work, distribute responsibility, breakup complex tasks, and provide useful feedback on work that is done. As a teacher I felt that I could contribute by helping my students better understand the merits of groupwork.

Initially, I believed that PBL is related specifically to the shift in the role from lecturer to facilitator; in the context of problembased learning but over time I began to see that it was much more complex than this. What became apparent is that I am to perform and manage increasingly diverse and ambiguous roles. The facilitator's position is one of being there to ensure that the team works effectively and that team member's learning needs are met. However, the facilitator is also there to promote the development of a team culture, to challenge, to help the balancing of task and process and to enable students to move from critical thought and then to critique. The position and type of power and understanding of students' perceptions and concerns are important components in what it means to be effective in the facilitation process ${ }^{9}$.

Investment in student preparation and understanding of PBL either during the admission process or prior to admission has proved to be a very valuable component in the successful implementation of the PBL programme ${ }^{8}$. If admission process continually emphasizes the nature of learning and the expectation of group participation, candidates will be made aware of what is expected of them and of any need to adapt. If students enter a PBL programme with insufficient awareness of its nature and of the expectations for their behaviour, it may be difficult to change their behaviours while at the same time expecting students to achieve content mastery ${ }^{8}$.

\section{Lack of familiarity with inquiry learning}

To start using inquiry, teachers must first be familiar with the conceptual frameworks that structure the subjects they teach and the ground rules that are important to particular disciplines. Questions, whether self-initiated or posted by others, are at the heart of learning by inquiry. While questions are a part of the traditional classroom, the source, the purpose, and the level of questions are quite different. In the traditional classroom, the teacher is frequently the questioner, and the purpose of questions is often to asses whether or not students have learned and absorbed particular information. When the teacher poses questions in an inquiry classroom, the questions are more reflective in nature. Appropriate inquiry techniques are important in an inquiry classroom especially at the initial stages where guided inquiry serves as the base for later, self-initiated questioning.

Inquiry learning requires being prepared mentally and physically for the process. The mental process might be more than a personal philosophical change about teaching and learning. The physical process has more to do with the preparation of the learning environment. The learning environment should be enriched with learning resources that will both stimulate and help answer the learners' inquiries. The internet if made available can be an important source of resource materials and resources for learning. Depending upon the nature of the activity, it might be necessary for the teacher to plan to have supplies and materials available for the students to explore some of their own questions. In addition, to start using inquiry, the teacher had to be prepared to become familiar with various types of questions and students "learn to learn" from them.

For the Solar Cell PBL single crystal silicon solar cells were used for the experiment. The students had access to the library, computer and internet resources. In the beginning the students had problems identifying the learning issues for the project. They were facing difficulties identifying their research direction as well as planning for their group action plans. Students found it difficult to identify the critical issues and to generate a coherent research design. They were often unclear about how they can relate what they were currently reading to what they already knew. They were also unfamiliar with different stages of the inquiry process, such as generating hypothesis, providing logical arguments, applying the correct formula, tabulating results, interpreting data, transforming data into a product. When the students had an appropriate learning context and the need to seek the necessary information, they also saw how things finally "come together". This is an aspect of critical reading that can be promoted within the framework of problem-based learning.

\section{Inadequate feedback on learning assessment}

Effective inquiry teachers are constantly assessing students. As they facilitate inquiry learning, they are monitoring the progress of the learner. Learning and assessing learning outcomes go hand-in-hand. Effective teachers are alert to the needs of particular students and the needs of the whole class. If there is an individual need, the teacher will work one-to-one with the student. If the whole class is experiencing a similar problem, the teacher will likely do whole-class mediation of the weakness. The important point is that assessing can dictate important instructional changes.

A one-to-one assessment was used for the Solar Cell PBL students following the end of a laboratory session. While one-on-one assessment is time consuming and laborious, it can be a very effective way to learn what student knows. Individual assessment has revealed my student's perception of the following:

- How the student views his individual effort.

- How well he participated in the group

- The quality of his work

- How satisfied the student is with his work

- Things he found difficult to figure out. 
- Things he found interesting and enjoyable

- How he might improve his performance

- How he viewed his work compared to that of an expert

- How his skills, knowledge and habits of mind improved

- What he viewed as important about the project or unit of study

Perhaps one of the best ways to really assess student learning from inquiry learning is through a narrative assessment. This narrative becomes an important report for the student, the family and the teacher. It is very important to see how integrated are the process of inquiry learning and the assessment of inquiry learning. Narrative provides a way for students to demonstrate not only what they know but also how it relates to their other knowledge,

their ways of seeing the world, and the ways they assess and analyse ideas.

Assessment, like good teaching is about many things at once: it should encourage interest, commitment and intellectual challenge, enhance student independence and responsibility, make the teacher's expectations unequivocal and show respect for our students as our learning partners ${ }^{10}$.

It is extremely important that there be a feedback from students to the teacher regarding the degree to which the learning objectives have been achieved. This feedback enables the teacher to make important changes in teaching and learning strategies. Through this feedback process, teachers begin to realise that all methods of learning are not equally effective. The approach to learning is not "one size fits all," and important modifications can and should be made depending on what each teacher finds helpful with particular students.

The feedback from the teacher to the learner is very important as well. The learner becomes more informed about what he knows, what skills he has, what conceptual understandings he has, and what nurtured habits of mind he possesses. He knows what specifics he needs to work on in order to achieve success. As he progresses with achieving these attributes, he develops more confidence in his ability to continue to learn. Giving feedback to students is integral to improving student learning. Barron et al. ${ }^{11}$, suggest that teachers can better guide and monitor projects by incorporating formative selfreflections by students, by creating a classroom culture that supports frequent feedback and assessment, and by finding ways for students to compare their work with others. Teachers can make students take their work seriously by incorporating opportunities that involve external audiences in assessing students' performance. This can take the form of a presentation or seminar.

\section{Scaffolding for PBL Success}

During the first meeting with the Solar Cell PBL group, I found out that all four students had no previous knowledge of the physics of solar cells and they had no previous background about solar energy. However they all have expressed great interest to know more about the topic. The students were given the trigger problem (Appendix 1) with the suggested references and they were scheduled to come back the following week to do the project. The following week they came in with a few references they borrowed from the library. I approached them the first week and suggested that they come up with a group action plan for the day. I noticed that they were all very busy reading from the references. The students were given time to sort out what they wish to do and after about one hour and a half I noticed that nobody has yet touched or attempted to look at any of the equipments on the

table or even venture to see what a solar cell looks like. They were all busy flipping the books. So I decided to ask if anybody can tell us what is a solar cell ? Have you seen a solar cell before? How is the structure (cross-section) of the solar cell? Can a solar cell be a hundred per cent efficient? I made them aware of the brittle solar cells which were on the table and reminded them to handle the cells with care. One of the students replied, "We have studied about a diode, but not a solar cell." So I suggested that it might be a good idea to find out the difference between a diode and a solar cell. The students did not attempt to make any circuit connections until nearly the end of the first session. I found that posing questions did helped students to "learn to learn." In the beginning I had to remind myself many times of my role as a facilitator in a PBL so as not to reveal direct answers but to be asking more questions to help in the scaffolding process of learning.

In the model of cognitive apprenticeship, developed by Collins et. al. ${ }^{12}$, scaffolding is described as a means of coaching students to the extent that they can perform intellectual tasks on their own. Success with PBL largely depends on whether students have been sufficiently prepared to take on certain new roles, such as those of inquiry seekers and collaborative team players in the classroom ${ }^{7}$. In a PBL classroom, for example, the teacher gauges the difference between what activities students can do on their own and what they need to learn to do to solve the problem. Then the teacher designs activities which offer just enough of a scaffold for students to overcome this gap of knowledge and skills ${ }^{13}$. Effective scaffolding includes activities that help students develop the right mindset, engage students with the problem, divide activities into manageable tasks, and direct students' attention to essential aspects of the learning goals. I believe that the effectiveness of PBL depends to a large degree on the scaffolding provided by facilitators to students. 


\section{Learning to Learn: Cooperative learning skills} In cooperative learning, students work together in small groups on a structured activity. They are individually accountable for their work, and the work of the group as a whole is also assessed. Cooperative groups work face-to-face and learn to work as a team. In small groups, students can share strengths and also develop their weaker skills. They develop their inter personnel skills. They learn to deal with conflict. When cooperative groups are guided by clear objectives, students engage in numerous activities that improve their understanding of the subject explored ${ }^{14}$.

In order to create an environment in which cooperative learning can take place, three things are necessary. First, students need to feel comfortable, but also challenged. Second, groups need to be small enough that everyone can contribute. Third, the task the students work together on must be clearly defined. Also, in cooperative learning small groups provide a place where:

- learners actively participate;

- teachers become learners at times, and learners sometimes teach;

- respect is given to every member;

- projects and questions interests and challenge students;

- diversity is celebrated, and all contributions are valued;

- students learn skills for resolving conflicts when they arise;

- members draws upon their past experience and knowledge;

- goals are clearly identified and used as a guide;

- research tools such as internet access are made available;

- Students are invested in their own learning.

Central to the effectiveness of PBL is the ability of students to work together to solve problems ${ }^{15}$. Teachers can encourage more beneficial and meaningful group work by prompting students to pool talents and resources and by guiding them to resolve conflicts while working together. Woods ${ }^{16}$ discussed some of these skills.

\section{Learning to Learn: Inquiry Skills}

Memorizing facts and information is not the most important skills in today's world. Facts change, and information is readily available. What is needed is an understanding of how to get and make sense of the mass of data. Through the process of inquiry, individuals construct much of their understanding of the natural and human-designed worlds. Inquiry implies a "need or want to know" premise. Inquiry is not so much seeking the right answer, because often there is none, but rather seeking appropriate resolutions to questions and issues. To educators, inquiry implies emphasis on the development of inquiry skills and the nurturing of inquiring attitudes or habits of mind that will enable individuals to continue the quest for knowledge throughout life.
In the Solar Cell PBL, students had to apply the following inquiry skills:

- Investigate the factors that affect the operation of the solar cell.

- Investigate the current-voltage (IV) characteristic of the solar cell. To obtain the IV characteristics the students will have to design a circuit using the equipments listed.

- Investigate the effect of the load resistance (R) on the IV characteristic of the solar cell. Students need to vary the values of the variable resistance and obtain the data for the current (I) and voltage (V) for various resistance (R) values.

- Investigate how to find the short circuit current $\left(\mathrm{I}_{\mathrm{sc}}\right)$, open circuit voltage $\left(\mathrm{V}_{\mathrm{oc}}\right)$ and the maximum power point $\left(\mathrm{P}_{\max }\right)$ for the solar cell. Students need to use the data obtained to plot a graph and identify the $\mathrm{V}_{\mathrm{oc}}, \mathrm{I}_{\mathrm{sc}}$ and $\mathrm{P}_{\max }$ values.

- Determine the fill factor (FF) of the solar cell. Students need to use the graph which they have plotted and the various points they have identified above to calculate the FF and the efficiency $(\eta)$ of the solar cells. This stage will involve application of the formulas to calculate the fill factor and the efficiency $(\eta)$ for the solar cells.

$$
\begin{gathered}
F F=\frac{V_{m p} I_{m p}}{V_{o c} I_{s c}} \\
\eta=\frac{P_{o}}{P_{i n}}=\frac{V_{o c} I_{s c} F F}{P_{i n}}
\end{gathered}
$$

- The incident power for standard calculations is usually taken as $P_{\text {in }}=1000$ Watts per square meter ${ }^{17}$.

- Determine the ideal resistance for the solar cell. This stage involved students using the collected data and computing the power $(P=I V)$. By plotting the graph of power $(P)$ versus resistance $(R)$ the students will then identify the ideal resistance which is the value of the resistance that will produce a maximum power on the graph.

- Investigate the effect of light levels on the solar cell. This can be done by using various bulbs and varying the number of bulbs. The experiment can be repeated to study of the effects of light levels on the fill factor and efficiency of the solar cells.

- Investigate the effect of the series and parallel combination of the solar cells on the current voltage characteristics of the solar cell. This involves joining the cells in series and parallel and notifying the changes in the current and voltage outputs.

- Match the combinations of cells that will suit with the application of a solar water fountain.

In PBL, students must seek and evaluate the information they acquire related to the problem they are given to solve. Activities that involve inquiry learning include problem framing, data gathering, divergent thinking or idea generation, evaluating alternatives and applying a solution to the problem $^{18}$. 


\section{Learning to Learn : Reflection Skills}

Reflection skills essentially give students the mental time and space to consider what they have been doing, value it, place it in context and make mature decisions about what to do next. It does not necessarily involve change, although it may lead to development or change.

Reflection involves focussed thinking about learning during the learning process. However, students often get caught up in completing a task and do not take time to reflect. Students learn from two kinds of reflection activities. The first focuses on the content, with students asking questions such as "What do I know now, and how can I use this information to meet the project's goal?" The second is reflection on the learning process, wherein is asked such questions as "How am I doing as a learner in this environment - as a self directed learner, as a problem solver, and as a collaborator? What are my strengths and weaknesses? How can I improve?" journal that records ideas, plans, strategies, and progress. It provides a written record of a student's train of thought. Specific log assignments can be given to help teachers track the thinking process and document student participation. For the Solar Cell PBL students were required to keep a laboratory log book. Students were also required to submit a project report at the end of the project.

Another potential assessment tool is concept mapping which also aid teachers in identifying errors in student learning ${ }^{24}$. Concept Mapping is also used in curriculum development. As teachers prepared concept maps of curriculum, they were able to improve the hierarchical arrangement of content with increased detail and greater integration of concepts. Concept mapping can not only provide a useful means of assessing knowledge acquisition of the students but it can also aid teachers in developing meaningful ill-structured problems for PBL.
While some mistakenly believe that interrupting the process of learning to reflect is too disruptive, on the contrarily, Kimbell et. al. ${ }^{19}$, have shown that interrupting the design or problem solving process to reflect actually improves problem solving and thinking processes. For the Solar Cell PBL, reflection activity has been practiced when students have completed a phase of the process. Reflection is linked to monitoring. Since monitoring occurs near the beginning and near the end of a task, using these times to remind students to write down their reflections can be productive.

\section{Learning to Learn: Assessment}

The ill-defined problems of PBL do not have answers that can be written in an answer key. It is difficult to develop multiple-choice questions that will measure creativity, critical thinking and teamwork skills. If PBL can meet the demands of the information age, educators will need to replace product-oriented assessment techniques with valid assessments for process-oriented education ${ }^{3}$. Boud and Felletti $^{7}$, in their meta analysis, point to the difficulties with testing knowledge as isolated facts out of context. Tchudi and Lafer ${ }^{20}$, describe traditional assessment as a game that engages the student in guessing what the teacher wants rather than demonstrating the best they can do. If $\mathrm{PBL}$ changes the game and learning is to be seen as relevant to life, new methods are needed for the teacher to be able to assess student progress. The emphasis should be on being able to locate the necessary information to solve the problem rather than memorizing facts ${ }^{21,22}$.

Gallagher et al. ${ }^{23}$, found that a laboratory notebook, just like scientists use, provided a means to record observations, store data, record proposed hypothesis, and list ideas that need to be recalled for later consideration. This lab notebook is easily expanded into a problem log whose format can be utilised in problems that are less science based. The problem log is a
At Leicester, the students of the interdisciplinary science courses are required to keep an individual portfolio containing their research, ideas, notes and results. The software that the students used to create individual portfolio is called "Microsoft OneNote", a component of Microsoft Office which is available on their PC. The portfolio is a collection points for all their research and laboratory work. The student's individual portfolio will be looked at by a member of staff and marked. Students received feedback on their portfolios including suggestions for how to improve. Portfolios take the place of lecture notes and laboratory notes and should build into a useful, personal repository of information. One of the advantages of keeping the

portfolio in OneNote is that everything that is put in is linkable, searchable, and filed in logical places.

Student outcomes from an inquiry-learning experience should focus on the following:

i. the development of information-processing and problemsolving skills (from observation and inference to synthesis and evaluation),

ii. the nurturing of habits of mind (from beliefs and opinion to respect for data and demand for verification

iii. applying these attributes to learning content,

iv. making sure the content is learned in a conceptual context of how the natural and human design worlds are organised, interrelate, communicate, and change.

Thus the focus of assessment of inquiry learning should be on the following:

- The degree to which the processing of learning skills has been developed.

- The degree to which the habits of mind of disciplines, have been nurtured 
- The degree to which the students have developed the content knowledge set in the context of broad understanding.

One problem in PBL is that while students are constantly encouraged to be engaged in the learning process, assessment of student learning might be inclined to focus instead on the final learning product. PBL teachers need to better understand meaningful ways of assessing student work to motivate learning. Woods ${ }^{16}$ clarifies a variety of topics related to assessment for $\mathrm{PBL}$.

The issue of student assessment, and how students are generally assessed in the traditional approach, is a crucial challenge to problem-based learning. In spite of all the good intentions of educators, there is no question that what is tested is the key factor in determining what is taught and learned. In spite of lots of good efforts to the contrary, student assessment, in the final analysis, is heavily oriented towards content mastery, mastery of "what we know." While this is important, other outcomes of problem based learning include conceptual understandings, skills development, and nurtured habits of mind, things that are difficult to assess by traditional paper-pencil type instruments. Portfolio assessment, which can evaluate learning progress, is one way of assessing the success of problem based learning and skills.

Unless the teacher can pinpoint these missing attributes, it will be very difficult to really help the learner. Tools are not readily available to help with this type of situation, because the focus has been on "what we know" rather than a focus on "how we come to know."

The appropriate use of new and emerging technologies would appear to offer much assistance in this area of student assessment. Generally, though, schools have not moved very far in using technology to measure skills development or to determine to what degree students have nurtured their own habits of the mind.

\section{Systematic Challenges}

There are lots of challenges to attempts to change education from an institution focussed on "what we know" to one focused on "how we come to know." Many, if not most, of these challenges are systematic in nature. Among the systematic elements in a school/community are: the administrative leadership and support, the instructional resources, the preparation and training of the teachers, the application of new and emerging technologies, the design of facilities and spaces, and the support and involvement of parents. If these elements are not aligned and supportive of inquiry method of learning, then the teacher may have difficulty implementing problem-based learning in the classroom.

Another challenge to PBL might be the attitudes of many parents, community leaders, and educators. Many parents might feel that students should memorize and know content, do lots of homework (even though it might be lacking in relevance), and do well on the tests and examinations. They might also think that focus on skills development is less important. Part of the work of implementing PBL is to make stakeholders aware of its importance.
School administrators might not view a school or a school district as a complex system that needs to be coordinated at every level. As a result, new and worthy goals might be set in the context of a school/community system that might have resisted, and might continue to resist, change. Wonderfully high standards might have been imposed, but teachers might not often be given enough guidance they need, or the techniques of teaching, which are required to ensure that students meet them.

\section{Conclusion}

PBL teachers constantly face challenges of encouraging students to go beyond the given information, to reflect on learning, and to actively consider how their knowledge might apply in novel contexts. Students are encouraged to constantly discover and to try new ways of learning. To facilitate these goals, teachers and students need to be provided with the appropriate and accessible pedagogical tools and support. As students develop more self-directed learning strategies, teachers can provide less scaffolding support.

If the focus is to be placed on new ways of learning, teachers cannot be educated in the old ways. Parents must be informed to understand and support PBL. New and emerging technologies must be used to enhance and manage learning. Administrators and community leaders must be develop the necessary support system, and appropriate instructional resources must be made available. All of the important systematic elements must become aligned with the learning outcomes.

\section{Acknowledgements}

I would like to thank Prof. Derek Raine for all his continuous help and discussions about PBL. I also would like to thank all the staff at the Centre of Interdisciplinary Science, University of Leicester for all their help which made my stay at Leicester a pleasant and fruitful one. Also I would like to thank University Science Malaysia for financing my visit to Leicester University.

\section{References}

1. Raine, D. and Symons, S. (2005) PBL in Context , Bridging Work and Education. Esa Poikela and Sari Poikela (Eds), (2005). Tempere University Press, pp.67, Experiences of PBL in Physics in UK Higher Education.

2. Student Handbook for Interdisciplinary Science (2008/2009), University of Leicester.

3. Project Leap (2005) $<$ www.le.ac.uk/leap>

4. Duch, J. B.; Groh, E. S. and Deborah, E. A. (2001) The Power of Problem-Based Learning. A practical "How To" for Teaching Undergraduate Courses in any Discipline. Stylus Publishing, USA.

5. Gallagher, S. A. (1997) Problem-based Learning: Where did it come from, what does it do, and where is it going? Journal for the Education of the Gifted, 20, (4), 332-62.

6. Albanese, M. A. and Mitchell, S. (1993) Problem-based learning: A review of literature on its outcomes and implementation issues. Academic Medicine, 68, 52-81.

7. Boud, D. and Felletti, G. (1997) The challenge of Problem -Based Learning. London, Kogan Page.

8. Schwartz , P.; Mennin S. and Webb G., (Eds) (2002) Problem-Based Learning : case studies, experience and practice. Kogan Page Ltd. 142-148. 
9. Maggi Saven-Baden, (2003) Facilitating Problem-Based Learning, Open University Press, McGraw Hill Education, England.

10. Ramsden, P. (1992) Learning to Teach in Higher Education, London: Routledge.

11. Barron, B.; Schwartz, D. L.; Vye, N. J.; Moore, A.; Petrosino, A.; Zech, L. and Bransford, J. D. (1998) Doing with understanding: Lessons from research on problem and project based learning. The Journal of the Learning Sciences, 7, 271-311.

12. Collins, A.; Brown and Newman (1987) Cognitive apprenticeship: Teaching the crafts of reading, writing, and mathematics. Technical Report, No. 403.

13. Greening, T. (1998) Scaffolding for success in PBL. Med Edu Online,

$<w w w . m e d-e d-o n l i n e . o r g>$

14. Johnson, D. W.; Johnson, R. T. and Smith, K. A. (1991) Cooperative learning: Increasing college faculty instructional productivity. ASHE-ERIC Higher learning Education Report No 4. Washington, USA.

15. Peterson, M. (1997) Skills to enhance Problem-Based Learning. Med Education Online 2, 3 $<$ www.med-ed-online.org >

16. Woods R. Donald, (2000) Problem-Based Learning: How to Gain the Most from PBL. McMaster University, Canada Publication.

17. Van Overstraeten, R. J. and Mertens, R. P. (1986), Physics Technology and Use of Photovoltaics, Bristoll, Adam Hilger, chapter 2.

18. Hmelo, C. E. and Ferrari, M. (1997) The problem-based learning tutorial: Cultivating higher order thinking skills. Journal for the Education of the Gifted, 20, (4), 401-422.

19. Kimbell, R.; Stables, K.; Wheeler, T.; Wosniak, A. and Kelly, V. (1991) Assessment of Performance in Design and Technology. School Examinations and Assessment Council, London W11 3JB.

20. Tchudi, S. and Lafer, S. (1996) The interdisplinary teachers' handbook: Integrated teaching across the curriculum. Portsmouth, NH: Boynton/Cook.

21. Gordon, P.; Rogers, A. and Comfort, M. (2001) A taste of problem-based learning increases achievement of urban minority middle-school students. Educational Horizons, 79 (4), 171-175.

22. Maxwell, N.; Bellisimo, Y. and Mergendoller, J. (2001) Problem-based learning: Modifying the medical school model for teaching high school economics. Social Studies, 92 (2), 73-78.

23. Gallagher, S.; Stepien, W.; Sher, B. and Workman, D. (1995) Implementing problem-based learning in science classrooms. School Science and mathematics, 95, 136146.

24. Novak, J. (1990) Concept mapping: A useful tool for science education. Journal of Research in Science Teaching, 27, 937-949.

25. Raine, D. J. and Symons, S. (eds) (2005) Possibilities : A practice Guide to Problem-Based Learning in Physics and Astronomy. Hull, UK: The Higher Education Academy Physical Sciences Centre.

\section{Appendix 1}

Solar Cell Experiment Trigger:

Crysalis Toys Ltd has a solar cell that they wish to use in a light powered water fountain. What range of combinations of cells and water fountain parameters would be available to the designers? Would there be any potential applications in micro-irrigation projects?

\section{Suggested References:}

- Physics of Solar Cells, Peter Wurfel (2005), Publisher Wiley-VCH Verlag $\mathrm{GmbH}$ and Co.

- Solar Electricity Second Edition edited by Thomas Marvart, Unesco Energy Engineering Series (2000). Publisher John Wiley and Sons Ltd.

- Fundamentals of solar cells : photovoltaic solar energy conversion

Fahrenbruch, Alan L., Academic (1983), ISBN: 0122476808 .

- High efficiency silicon solar cells Green, Martin A., Trans Tech Publications (1987). ISBN: 0878495371.

- An introduction to materials / Units 10-11, Solar cells Open University. Introduction to Materials Course Team., Open University Press (1973).

- Solar electricity : engineering of photovoltaic systems Lorenzo, Eduardo. Institute of Solar Energy, Polytechnic University of Madrid (1994). ISBN: 364041994.

- Sunlight to electricity : prospects for solar energy conversion by photovoltaics Merrigan, Joseph A., M. I. T. Press (1985). ISBN: 0262131161.

- Solar cells Backus, Charles E., IEEE Press (1976). ISBN : 0879420693.

- An experiment to measure the I-V characteristics of a silicon solar cell, Michael J Morgan, Greg Jakovidis and Ian McLeod, Physics Education (1994).

- Pumping Water for Irrigation Using Solar Energy, H. J Helikson, D. Z. Haman and C. D. Baird. University of Florida, Fact Sheet EES-63, November, 1991.

- <www.brillianz.co.uk/data/documents/Lumen.pdf>

- <www.volkerquaschning.de/articles/fundamentals1/ index_e.html>

\section{Equipment List:}

Solar cells, ammeter, voltmeter, ADC-11 Data Logger and software, lamps and 40W, $60 \mathrm{~W}$ light bulbs, connecting wires, electronic circuit-board, decade variable resistance box $(0-100 \mathrm{k} \Omega), 1 \Omega$ resistor.

\section{Assessment:}

All students are required to submit a laboratory report. 